\title{
EKSISTENSI TANAH WAKAF DALAM PEMANFAATANNYA UNTUK KEMAJUAN KESEJAHTERAAN UMUM*
}

\author{
Salmawati \\ Fakultas Hukum, Universitas Muslim Indonesia \\ Jalan Urip Sumohardjo Km. 5 Makassar, Sulawesi Selatan \\ e-mail: salmawati.ilyas@umi.ac.id
}

\begin{abstract}
The research objective is to find out, analyze The existence of land endowments in its use for the advancement of general welfare. This study uses a normative legal research type (doctrinal) to analyze phenomena or (social) phenomena that occur in society that are related to the legal reality in society, namely various laws and regulations in the land endowments. The results showed that, (the existence of waqf land is perpetuating the benefits of waqf objects in accordance with the purpose of waqf, namely realizing the economic potential and benefits of waqf property for the sake of worship and to promote general welfare.
\end{abstract}

Keywords: Existence; Utilization; Land; Endowment.

\begin{abstract}
Abstrak
Tujuan Penelitian, adalah untuk mengetahui, menganalisis tentang eksistensi tanah wakaf dalam pemanfaatannya untuk kemajuan kesejahteraan umum. Penelitian ini menggunakan tipe penelitian hukum normative (doctrinal) untuk menganalisis fenomena atau gejala (sosial) yang terjadi dalam masyarakat yang berhubungan dengan realitas hukum dalam masyarakat yakni berbagai peraturan perundang-undangan di bidang tanah wakaf. Hasil penelitian menunjukkan bahwa, (eksistensi tanah wakaf adalah mengekalkan manfaat benda wakaf sesuai dengan tujuan wakaf, yakni mewujudkan potensi dan manfaat ekonomis harta benda wakaf untuk kepentingan ibadah dan untuk memajukan kesejahteraan umum.
\end{abstract}

Kata Kunci: Eksistensi; Pemanfaatan; Tanah; Wakaf.

\footnotetext{
* Naskah diterima: 27 Oktober 2018, direvisi: 2 Desember 2018, disetujui untuk terbit: 10 Januari 2019 Doi: $\underline{10.3376 / j c h . v 4 i 2.106}$
} 


\section{PENDAHULUAN}

Badan Wakaf sebagai salah satu lembaga Islam yang berkembang di Indonesia yang pada umumnya berupa tanah milik, erat sekali hubungannya dengan sector ekonomi pembangunan nasional (Munir, 2013: 162). Di Indonesia, dengan meningkatnya pembangunan, berimplikasi pada meningkat pula akan kebutuhan tanah dengan berbagai tingkat kebutuhan, baik sifatnya kebutuhan perorangan dan kepentingan umum yang berkaitan dengan pemenuhan prasarana seperti, jalan, pasar, sekolah dan fasilitas umum lainnya (Hipan, Nur \& Djanggih, 2018: 206).

Hal tersebut menuntut peran penting antara masyarakat dan pemerintah untuk memanfaatkan tanah secara efisien dengan maksud untuk menghindari pemanfaatan tanah yang kurang bermanfaat (Permatasari, Adjie \& Djanggih, 2018: 1). Oleh karena itu, pemanfaatan tanah harus sesuai dengan keadaan dan sifatnya, sehingga akan terwujudnya kesejahteraan bagi masyarakat dan negara (Ramadhona, 2017: 74).

Wakaf adalah salah satu pranata keagamaan yang bila dikelola secara efektif dan efisien sesuai dengan prinsif syariah akan memiliki potensi dan manfaat ekonomi yang tidak hanya bermanfaat untuk kepentingan ibadah, namun demikian, Tanah wakaf dalam praktiknya belum sepenuh berjalan tertib dan efesien. Dalam berbagai kasus, harta benda wakaf tidak terpelihara sebagaimana semestinya, terlantar, atau beralih ke pihak ketiga secara melawan hukum, akibat kelalaian Nadzir maupun masyarakat, fungsinya melenceng dari tujuan semula.

Undang-undang Republik Indonesia Nomor 41 Tahun 2004 Tentang Wakaf BAB I Pasal I Ayat (1) menegaskan bahwa "Wakaf adalah Perbuatan Hukum Wakif untuk memisahkan dan atau menyerahkan sebagian harta benda miliknya untuk dimanfaatkan selamanya atau jangka waktu tertentu sesuai dengan kepentingannya guna keperluan ibadah dan/atau kesejahteraan umum menurut syariah". Dengan demikian fungsi wakaf sesuai Undang-undang tersebut dalam pasal 5, bahwa "Wakaf berfungsi mewujudkan potensi dan manfaat ekonomis harta benda wakaf untuk kepentingan ibadah dan untuk memajukan kesejahteraan umum "oleh karena itu, agar upaya pelaksanaan wakaf di Indonesia dapat berjalan tertib dan sistematis maka pemerintah dalam hal ini Kementerian Agama mengembangkan lembaga wakaf dan memberdayakan potensi wakaf sehingga akan berdampak positif terhadap kehidupan sosial dan ekonomi umat Islam. Dan adanya pernyataan Tentang peruntukan harta benda wakaf yaitu Peraturan Pemerintah Tentang Undang-Undang Republik Indonesia No.41 Tahun 2004 yang terdapat dalam BAB I, Bagian Kedelapan Tentang Peruntukan Harta Benda Wakaf, Pasal 22, huruf (d) dan (e) yaitu: Dalam rangka mencapai tujuan dan fungsi wakaf, maka harta benda wakaf hanya dapat diperuntukkan bagi: 
Salmawati: Eksistensi Tanah Wakaf Dalam Pemanfaatannya Untuk Kemajuan...

a. Sarana dan kegiatan ibadah;

b. Sarana dan kegiatan pendidikan serta kesehatan;

c. Batuan kepada fakir miskin, anak terlantar, yatim piatu, beasiswa

d. Kemajuan dan peningkatan ekonomi umat.

Berdasarkan undang-undang tersebut kiranya dapat dipahami bahwa cara yang digunakan adalah harus sesuai dengan peraturan yang ada. Namun, biasanya bila seseorang akan mewakafkan tanah miliknya, wakif menunjuk Nadzir untuk menyelesaikan segala sesuatunya yang berhubungan dengan pelaksanaan wakaf. Walaupun tujuan wakaf digunakan untuk kepentingan umum serta kesejahteraan masyarakat dalam pengalihfungsian tanah wakaf.

Pemanfaatan tanah wakaf sangat dibutuhkan untuk meningkatkan perekonomian umat dan yang paling berperan dalam hal ini adalah Nadzir sebagai penerima amanah dari pewakif atau orang yang mewakafkan harta bendanya untuk keperluan ibadah. Untuk melaksanakan amanah dari si pewakif seharusnya Nadzir mempunyai kemampuan dan manajemen yang baik.

Salah satu masalah di bidang keagamaan yang menyangkut pelaksanaan tugas-tugas keagrariaan adalah perwakafan tanah milik. Begitu pentingnya masalah perwakafan tanah milik tersebut ditinjau dari sudut Undangundang Nomor 5 Tahun 1960 tentang Peraturan Dasar Pokok-pokok Agraria, sehingga perlu diatur dalam Peraturan Pemerintah yang berhubungan dengan aspek pendaftaran tanah sehingga memberikan jaminan kepastian hukum (Yarsina, 2018: 167).

Filosofi yang terkandung dalam amalan wakaf menghendaki agar harta wakaf itu tidak boleh hanya dipendam tanpa hasil yang dinikmati oleh penerima wakaf. Makin banyak hasil yang diperoleh makin besar pula pahala yang mengalir. Sebagai ibadah yang berdimensi sosial, maka wakaf mempunyai filosofi dan hikmah yang sangat rasional bermanfaat bagi kehidupan umat. Manfaat ini sudah terbukti dalam sejarah umat Islam, sejak awal sampai kini. Hal terebut memang sangat tergantung kepada kemampuan umat sendiri untuk mengaktualisasikan filosofi dan hikmah wakaf dalam kehidupan umat. Kini manfaat dan hikmah ini belum diwujudkan secara optimal, yang disebabkan oleh beberapa faktor internal yang lebih menentukan potensi wakaf itu belum teraktualisasikan sepenuhnya dalam kehidupan umat, misalnya kurangnya perhatian terhadap potensi wakaf, dan terbatasnya kemampuan para pengelola (Nadzir) wakaf untuk mendayagunakan secara efektif dan produktif.

Langkah strategis yang ditempuh adalah dengan meningkatkan peran wakaf sebagai pranata keagamaan yang tidak terbatas pada sarana ibadah dan sosial, namun lebih pada meningkatkan kesejahteraan umum dengan pengembangan pemanfaatan wakaf berdasarkan prinsip syariah. 
Sehubungan dengan hal tersebut, dapat dikatakan bahwa pelaksanaan wakaf dalam masyarakat belum berjalan secara tertib dan efisien. Hal ini nampak pada kasus harta benda wakaf tidak terpelihara secara baik, atau harta benda wakaf diterlantarkan atau beralih ke pihak lain dengan cara melawan hukum. Hal tersebut disebabkan pada kelalaian atau ketidak mampuan Nazhir pada pengelolaan dan pengembangannya serta sikap masyarakat yang kurang memahami status benda wakaf tersebut.

Berangkat dari isu yang telah dikemukakan, penting bagi penulis untuk melakukan kajian karya ilmiah ini dengan topik "Eksistensi Tanah Wakaf Dalam Pemanfaatannya Untuk Kemajuan Kesejahteraan Umum".

\section{METODE PENELITIAN}

Penelitian ini menggunakan tipe penelitian hukum normative (doctrinal) untuk menganalisis fenomena atau gejala (sosial) yang terjadi dalam masyarakat yang berhubungan dengan realitas hukum dalam masyarakat yakni berbagai peraturan perundang-undangan di bidang tanah wakaf (Martono, 2010: 27). Penelitian menggunakan pendekatan kualitatif untuk menganalisis keberadaan tanah wakaf dan Pemanfaatannya.

\section{HASIL DAN PEMBAHASAN}

Wakaf merupakan bentuk muamalah yang bersifat kebendaan yang telah ada semenjak kehidupan bermasyarakat itu ada. Setiap komunitas manusia selalu menyediakan fasilitis yang bersifat perkhidmatan umum yang diperlukan manusia secara bersama, seperti tempat ibadah, jalan raya, sumber air, serta fasilitas umum lainnya, dan lazimnya semenjak zaman dahulu kala banyak yang berbentuk wakaf. Perwakafan atau wakaf merupakan pranata dalam keagamaan Islam yang sudah mapan. Dalam hukum Islam, wakaf tersebut termasuk ke dalam kategori ibadah kemasyarakatan (Ibadah ijtima'ayyah). Sepanjang sejarah Islam, wakaf merupakan sarana dan modal yang amat penting dalam memajukan perkembangan agama.

Membicarakan soal menafkahkan harta dan termasuk di dalamnya mewakafkan harta yang dimilikinya, Berdasarkan dalam Al-Qur'an, institusi Wakaf disandarkan pada konsep dasar ajaran Islam tentang "amal saleh" sebagai wujud dari keimanan atau iman seseorang. Hal ini secara tegas disebutkan dalam Ali Imran ayat 92 yang artinya: (Departemen Agama, 2006: 49).

Kamu sekali-kali tidak sampai kepada kebajikan (yang sempurna), sebelum kamu menafkahkan sebahagian harta yang kamu cintai. dan apa saja yang kamu nafkahkan Maka Sesungguhnya Allah mengetahuinya.

Selain Ayat 92 Surat Ali Imran, disebutkan pula dalam surat Al-Baqarah Ayat 261, yang artinya: (Departemen Agama, 2006: 34)

Perumpamaan (nafkah yang dikeluarkan oleh) orang-orang yang menafkahkan hartanya di jalan Allah adalah serupa dengan sebutir benih yang menumbuhkan tujuh bulir, pada tiap-tiap bulir seratus biji. Allah 
Salmawati: Eksistensi Tanah Wakaf Dalam Pemanfaatannya Untuk Kemajuan...

melipat gandakan (ganjaran) bagi siapa yang dia kehendaki. dan Allah Maha luas (karunia-Nya) lagi Maha Mengetahui.

Semua manusia akan mati. Mari renungkan sejenak, pada saat dilahirkan, kita dalam keadaan miskin; pada saat meninggal kita juga akan kembali miskin. Tanpa dapat disangkal lagi bahwa setelah meninggal, maka semuanya berakhir kecuali hanya tiga hal, yaitu; ilmu yang bermanfaat, anak saleh, dan amal jariyah. Dalam konteks tersebut bahwa dapat dimaknai, wakaf merupakan bentuk amal jariyah yang mengalir terus pahalanya. Wakaf merupakan sedekah/jariyah yang berperan sangat penting bagi umat guna tercapainya kehidupan yang bahagia di dunia dan di akhirat. Sebagaimana sabda Rasulullah SAW yang artinya:

"Apabila manusia wafat, terputuslah amal perbuatannya, kecuali tiga hal, yaitu sedekah jariyah, atau ilmu pengetahuan yang dimanfaatkan, atau anak saleh yang mendoakan orang tuanya. "(Sabiq, 1988: 148).

Dengan demikian, agar amal saleh dan amal jariyah berlangsung terusmenerus, seseorang perlu melakukan shadaqah jariyah, memiliki ilmu yang bermanfaat dan adanya anak saleh yang mendoakannya. Meskipun demikian apabila secara akumulatif ketiganya tidak mungkin dilakukan sekaligus, maka secara alternatif jika salah satu dari tiga hal tersebut Nabi Muhammad SAW itu, dapat dilakukan oleh seorang muslim sudah cukup dipandang amalnya selalu mengalir sekalipun orangnya sudah meninggal, dan tidak ada sadaqoh jariyah yang lebih kekal selain dari wakaf.
Hakikat 'wakaf' dalam makna umum dapatlah dideskripsikan sebagai suatu perilaku atau tindakan subyek hukum (seorang manusia atau bukan manusia yang disebut badan hukum) yang dilakukan karena motivasi philantrofis atau dorongan sifat kedermawanan untuk diserahkan penggunaan dan pemanfaatannya pada pihak lain.

Jika hakikat wakaf itu dilihat dari kacamata keagamaan (Islam) maka perbuatan berwakaf itu dikaitkan dengan nilai dan sifat benda yang diwakafkan untuk dapat dimanfaatkan buat selamalamanya dengan syarat bahwa penggunaan benda itu untuk kepentingan ibadah baik langsung maupun tidak langsung atau setidak-tidaknya peruntukan yang tidak bertentangan dengan hukum (agama) yang lazimnya disebut sebagai Syari'at Islam. Makna yang lebih dalam lagi adalah timbulnya kesadaran akan kepedulian terhadap suatu kepentingan yang terletak di luar dirinya.

Preposisi ini dapat dicermati dari rumusan kalimat yang menjadi dasar pertimbangan (konsiderans) UndangUndang No 41 Tahun 2004 Tentang Wakaf. Dalam pertimbangan pertama dikatakan bahwa:

"Wakaf adalah lembaga keagamaan yang memiliki potensi dan manfaat ekonomi perlu dikelola secara efektif dan efisien untuk kepentingan ibadah dan kesejahteraan umum. Wakaf merupakan perbuatan hukum yang telah lama hidup dan dilaksanakan dalam masyarakat, yang pengaturannya masih belum lengkap serta 
masih tersebar dalam berbagai peraturan perundang-undangan"

Dari dua butir pertimbangan di atas jika dilihat dan ditinjau dari sudut (cara) pandang filsafati dapatlah ditangkap nilainilai hakiki dari wakaf. Untuk dapat menggali nilai-nilai, yang terkandung dalam wakaf, hendaknya dipahami dengan baik bahwa pertama ia merupakan lembaga keagamaan atau sesuatu ritualvertikal yang memperlakukan sesuatu benda yang bersifat ekonomis dan dengan memanfaatkannya sebagai sarana untuk tujuan yang luhur yang suci (sakral) dan terpuji. Kedua, ia juga sebagai pranata sosial-horizontal, maknanya adalah bahwa di samping lembaga keagamaan yang bersifat ilahiah dan perbuatan yang dilakukan dengan ikhlas yang dalam bahasa agama adalah 'lillahi ta'ala (Arab: artinya sesuatu yang dilakukan hanya karena dan demi Tuhan tanpa pamrih untuk memperoleh imbalan dari orang lain atas perbuatannya itu); sekali lagi artinya bermotif semata-mata hanya untuk sarana mendekatkan diri atau taqarrub (Arab) agar memperoleh ridho, perkenan dan pahala dari sisi-Nya, tetapi juga bersifat sosial kemasyarakatan. Artinya sebagai lembaga hukum yang hidup meskipun berasal dari sumber agama namun dalam realitas operasionalnya perwakafan itu berasal dari masyarakat, dikelola oleh warga masyarakat dan tujuannya digunakan untuk kepentingan masyarakat umum atau setidak-tidaknya untuk satu umat beragama tertentu (dalam hal ini Islam).
Asas kemanfaatan benda wakaf menjadi landasan yang paling relevan dengan keberadaan benda itu sendiri lebih-lebih ibadah wakaf oleh para ulama dikategorikan sebagai amal ibadah shadaqah jariyyah yang memiliki nilai pahala yang terus mengalir walaupun yang melakukannya telah meninggal dunia. Tentu saja, dalam pandangan yang paling sederhana sekalipun, bahwa kontinyuitas pahala yang dimaksud itu karena terkait dengan aspek kemanfaatan yang bisa diambil secara berkesinambungan oleh pihak kebijakan (kepentingan masyarakat banyak).

Perwakafan tanah dan tanah wakaf di Indonesia adalah termasuk dalam bidang Hukum Agraria, yaitu sebagai perangkat peraturan yang mengatur tentang bagaimana penggunaan dan pemanfaatan bumi, air dan ruang angkasa Indonesia, untuk kesejaheraan bersama seluruh rakyat Indonesia, air dan ruang angkasa serta hubungan bumi, air dan ruang angkasa tersebut. Perwakafan di Indonesia umumnya berobyek tanah, maka masalah perwakafan tanah diatur dalam Undang-Undang Nomor 5 Tahun 1960 tentang Peraturan Dasar PokokPokok Agraria (UUPA) dalam Pasal 49 ayat (3) yang berbunyi:

"Perwakafan tanah milik dilindungi dan diatur dengan Peraturan Pemerintah".

Di Indonesia wakaf dikenal dan dilaksanakan oleh umat Islam sejak agama Islam masuk ke Indonesia yang juga menjadi salah satu penunjang pengembangan agama dan masyarakat 
Salmawati: Eksistensi Tanah Wakaf Dalam Pemanfaatannya Untuk Kemajuan...

Islam. Salah satu pilar atau komponen dari Sistem Hukum Nasional yaitu Hukum Islam (Arifin, 2001:40-41), yang di dalamnya terdapat (Lembaga) Hukum Wakaf (Rasyid, 1998:37), Masalah wakaf khususnya perwakafan tanah milik, jika dikaitkan dengan Undang-undang Nomor 5 Tahun 1960 tentang Peraturan Dasar Pokok Agraria adalah sangat penting, sehingga kemudian perlu diatur dalam Peraturan Pemerintah Nomor 28 Tahun 1977, tentang Perwakafan Tanah Milik yang kemudian dikuatkan dengan dikeluarkannya Undang-undang Nomor 41 Tahun 2004, tentang Wakaf dan Peraturan Pemerintah Nomor 42 Tahun 2006, sebagai aturan pelaksanaannya, sehingga wakaf tanah dapat digunakan sebagai salah satu sarana pengembangan penghidupan beragama dan bermasyarakat dan semakin luas dan kongkrit, khususnya bagi umat Islam dalam rangka mencapai kesejahteraan materiil dan sprituil menuju masyarakat adil dan makmur (Departeman Agama, 2003: 1).

Di tengah problem sosial masyarakat Indonesia dan tuntutan akan kesejahteraan ekonomi akhir-akhir ini keberadaan lembaga wakaf menjadi sangat strategis. Di samping sebagai salah satu aspek ajaran Islam yang berdimensi spiritual, wakaf juga merupakan ajaran yang menekankan pentingnya kesejahteraan ekonomi (dimensi sosial) (Departeman Agama, 2006: 1).

Obyek perwakafan di Indonesia umumnya masih berupa tanah, sehingga Undang-undang tentang Peraturan Dasar
Pokok-pokok Agraria (UUPA) yaitu Undang-undang Nomor 5 Tahun 1960 yang disahkan pada tanggal 24 September 1960, dalam Pasal 49 ayat (3) mengatur bahwa: "Perwakafan tanah milik dilindungi dan diatur dengan Peraturan Pemerintah" (Departemen Agama, 2001: 80).

Selanjutnya untuk memberikan perlindungan dan kepastian hukum dalam soal perwakafan tanah milik, pemerintah telah mengeluarkan Peraturan Pemerintah Republik Indonesia Nomor 28 Tahun 1977, tentang Perwakafan tanah milik, yang dalam konsideran menyebutkan:

a. Bahwa wakaf adalah suatu lembaga keagamaan yang dapat dipergunakan sebagai salah satu sarana guna pengembangan kehidupan beragama, khususnya bagi umat yang beragama Islam, dalam rangka mencapai kesejahteraan spirituil dan materiil menuju masyarakat adil dan makmur berdasarkan Pancasila.

b. Bahwa Peraturan Perundangundangan yang ada sekarang ini yang mengatur tentang perwakafan tanah milik, selain belum memenuhi kebutuhan akan cara-cara perwakafan, juga membuka kemungkinan timbulnya hal-hal yang tidak diinginkan disebabkan tidak adanya data-data yang nyata dan lengkap mengenai tanah-tanah yang diwakafkan.

c. Bahwa sesuai dengan ketentuan Pasal 14 ayat (1) huruf b dan Pasal 49 ayat (3) Undang-undang 5 Tahun 1960, maka dipandang perlu untuk 
mengatur tatacara dan pendaftaran perwakafan tanah milik dengan Peraturan Pemerintah (Departemen Agama, 2006: 80).

Sejalan dengan Undang-undang Republik Indonesia Nomor 25 Tahun 2000 tentang Program Pembangunan Nasional (PROPENAS) Tahun 2000-2004 dan Ketetapan MPR Nomor IV/MPR/1999, tentang Garis-garis Besar Haluan Negara Tahun 1999-2004, yang antara lain menetapkan arah kebijaksanaan pembangunan hukum, maka penyusunan rencana Undangundang (RUU) Wakaf merupakan bagian yang inhern dengan penataan sistem hukum nasional, seperti dimaksud dalam GBHN adalah yang bersifat menyeluruh dan terpadu dengan mengakui dan menghormati hukum agama dan hukum adat. Dengan adanya Undang-undang Wakaf, maka pengembangan wakaf memperoleh dasar hukum yang lebih kuat, antara lain untuk memberikan kepastian hukum kepada wakif (pewakaf), nadhir (pengelola wakaf), dan maukuf 'alaih (yang berhak menerima hasil wakaf) (Departemen Agama, 2006: 55).

Kemudian pada tanggal 27 Oktober 2004 Pemerintah dengan persetujuan DPRRI telah mensyahkan Undangundang Nomor 41 Tahun 2004, tentang "Wakaf", yang salah satu konsiderannya menyebutkan: "Bahwa Lembaga Wakaf sebagai Pranata Keagamaan memiliki potensi dan manfaat ekonomi perlu dikelola secara efektif dan efesien untuk kepentingan ibadah dan memajukan kesejahteraan umum (Departemen
Agama, 2006: 1). Kemudian untuk melengkapi aturan yang ada tentang wakaf, maka pada tanggal 15 Desember 2006, diterbitkan Peraturan Pemerintah Nomor 42 Tahun 2006 sebagai aturan Pelaksana Undang-undang Nomor 41 Tahu 2004 tentang Wakaf. Kesemua peraturan perundangan tersebut dikeluarkan dalam rangka untuk memberikan payung hukum di dalam masalah perwakafan dan pengelolaannya.

Upaya dan perhatian pemerintah terhadap lembaga perwakafan tersebut menunjukkan betapa pentingnya lembaga wakaf dalam rangka meningkatkan kesejahteraan sosial dan ekonomi umat. Dalam praktek di masyarakat presentase peruntukan tanah wakaf lebih banyak ditujukan untuk hal-hal yang bersifat keibadatan misalnya untuk masjid, mushalla, panti asuhan, pondok pesantren yang tidak mempunyai nilai produktif. Dari sisi ekonomi padahal sebenarnya lembaga wakaf dapat saja diperuntukkan bagi hal-hal yang mengandung suatu kebaikan dan kemaslahatan masyarakat luas yang bersifat produktif selama tidak menyalahi ajaran agama Islam. Hal tersebut sebagaimana yang telah dilakukan oleh beberapa Negara Islam Timur Tengah yang telah mempunyai pengalaman yang cukup matang di bidang perwakafan, contohnya Negara Mesir. Dimana pemerintahan Mesir di pimpin oleh Presiden Jamal Abdul Naser memerlukan pinjaman uang, pemerintah meminjam ke badan wakaf Al Azhar (pinjaman tanpa bunga) tidak ke lembagalembaga moneter internasional dan tidak 
Salmawati: Eksistensi Tanah Wakaf Dalam Pemanfaatannya Untuk Kemajuan...

suka ke negeri-negeri lain (Djatniko,1992: $10)$.

Sejalan dengan sasaran yang ingin diwujudkan melalui Undang-undang Wakaf atau peraturan-peraturan Tentang Wakaf diantaranya:

1. Terciptanya tertib hukum dan tertib aturan tentang wakaf dalam wadah Negara Republik Indonesia.

2. Terjaminnya kesinambungan dan optimalisasi pengelolaan dan pemanfaatan benda wakaf sesuai dengan sistem ekonomi syariah;

3. Memberikan instrument untuk mengembangkan rasa tanggung jawab bagi para pihak yang mendapat kepercayaan mengelola wakaf,

4. Melindungi dan memberikan rasa aman bagi wakif dan Nazhir dan mauquf alaih, baik perorangan maupun badan hukum.

5. Tersedianya landasan peraturan perundang-undangan bagi pembentukan dan pelaksanaan peran, tugas dan fungsi Badan/Pusat Wakaf Indonesia dan Terwujudnya akumulasi asset wakaf sebagai alternative sumber pendanaan bagi pembangunan kesejahteraan masyarakat.

Sesuai sejarah Indonesia, wakaf telah di kenal dan dilaksanakan oleh umat islam sejak agama islam masuk di Indonesia. Sebagai suatu lembaga Islam, namun Secara umum orang lebih mengenal istilah wakaf hanya untuk orang muslim (orang yang beragama Islam), keberadaan wakaf di Indonesia adalah digunakan untuk masjid, musholla, sekolah, rumah, jariyah, tanah pertanian, yatim piatu.

Dari aspek sosial, Pemanfaatan tanah wakaf sebagai kepentingan peribadatan sangat efektif, akan tetapi tidak memberi dampak positif terhadap perekonomian masyarakat. Sehingga, jika tanah wakaf tidak dilakukan secara produktif, maka kesejahteraan masyarakat dari peran lembaga perwakafan tidak akan terealisasi dengan optimal.

Di Indonesia, merujuk data Departemen Agama RI jumlah tanah wakaf mencapai 49.052,36 Ha. Jumlah luas tanah wakaf tersebut sebagian besar dimanfaatkan sebagai sarana tempat ibadah.

Pemanfaatan Wakaf bukan hanya untuk sebagai sarana tempat ibadah dan tempat penguburan, dengan dikelola secara produktif dan professional. Harta wakaf berupa tanah maupun uang bisa membantu pemerintah dalam mengentaskan kemiskinan dan bahkan mewujudkan kesejahteraan umum, bukan hanya umat Islam.

Besarnya jumlah benda-benda wakaf, khususnya tanah dan bangunan menjadi peluang yang sangat besar bagi pengembangan ekonomi umat di masa mendatang dan untuk memajukan kesejahteraan umum, tanah wakaf yang begitu luas dan menempati beberapa lokasi yang strategis memungkinkan dikelola dan dikembangkan secara produktif. Sebagai contoh pemanfaatan tanah wakaf untuk kesejahteraan umum yakni peran tanah wakaf dalam bidang 
pendidikan sebenarnya sangat banyak, khususnya tanah wakaf yang dikelola oleh pesantren-pesantren yang tersebar di seluruh nusantara. Selain itu terdapat lembaga atau badan hukum yang mengelola tanah wakaf yang diperuntukkan khusus untuk pengelolaan perguruan tinggi, seperti Badan wakaf Pondok Modern Gontor Ponogoro, Badan Wakaf Universitas Islam Indonesia (UII) Yogyakarta, Badan Wakaf Universitas Muslim Indonesia (UMI) Makassar. Yayasan wakaf seperti Pondok Modern Gontor, UII Yogyakarta dan UMI Makassar tersebut mempunyai tanah wakaf yang sangat luas, yang berasal dari wakaf murni atau asli, dari pemberian wakaf orang lain dan dari pembelian.

Tanah wakaf yang dikelola oleh badan hukum tersebut diatas ternyata pengelolaannya sangat efektif dan sangat berguna dalam bidang pengembangan pendidikan pada umumnya serta dapat membantu untuk kesejahteraan umum.

Dari segi pemanfaatan sumber daya alam (tanah), Indonesia merupakan jumlah wakaf terbesar di dunia. Sehingga memberi tantangan untuk pemanfaatan harta wakaf secara optimal dengan maksud agar tanah wakaf tersebut menjadikan umat Islam di Indonesia sejahtera sesuai dengan kedudukan wakaf dalam ajaran Agama Islam.

Banyaknya tanah wakaf di Indonesia tidak lain karena didukung dengan jumlah penduduk Indonesia dengan mayoritas penduduknya adalah Agama Islam. Sehingga dapat dikatakan, bahwa wakaf merupakan modal penting bangsa
Indonesia yang seyogyanya di fungsikan secara maksimal guna terwujudkan perwakafan Indonesia yang produktif

Berdasarkan uraian yang di atas akan dapat dipahami bahwa wakaf termasuk di dalamnya wakaf tanah mempunyai kontribusi solutif terhadap persoalanpersoalan ekonomi kemasyarakatan dalam arti kata wakaf tanah mengandung potensi sumber daya ekonomi umat. Wakaf dalam tataran idiologis berbicara tentang bagaimana nilai-nilai yang seharusnya diwujudkan oleh dan untuk umat Islam, sedangkan pada wilayah paradigma sosial-ekonomis, wakaf menjadi jawaban konkrit dalam menghadapi realitas problematika kehidupan masyarakat. Salah satu konsep sumber daya ekonomi apabila dikaitkan dengan tanah mungkin dapat dipahami, bahwa tanah merupakan "Natural Resources" (sumber daya alam), sedangkan manusia sebagai "Human Resources" (sumber daya manusia). Dalam pengalaman sejarah, ekonomi suatu bangsa dan negara akan dapat tumbuh dan berkembang apabila kedua factor tersebut dapat dikelola sebaik mungkin dengan menggunakan penemuan-penemuan baru dalam iptek (ilmu pengetahuan dan teknologi). Bertolak dari pemikiran di atas, maka tanah wakaf sebagai suatu lembaga sosial Islam, pada hakekatnya mempunyai fungsi yang sama dapat digunakan sebagai salah satu sumber daya ekonomi. Artinya penggunaan tanah wakaf tidak terbatas hanya untuk keperluan kegiatankegiatan tertentu saja berdasarkan orientasi konvensional, seperti 
Salmawati: Eksistensi Tanah Wakaf Dalam Pemanfaatannya Untuk Kemajuan...

pendidikan, masjid, pondok pesantren, panti-panti asuhan, dan lain-lain, tetapi tanah wakaf dalam pengertian makro dapat pula dimanfaatkan untuk kegiatankegiatan ekonomi lainnya, seperti rumah sakit, pertokoan, pertanian, peternakan, industri, pertambangan, real estate, hotel, restaurant, dan lain-lain. Kedudukan tanahnya tetap sebagai tanah wakaf, namun hasilnya dapat dimanfaatkan secara lebih optimal. Hal ini merupakan salah satu alternatif untuk mengoptimalkan fungsi wakaf itu sendiri (Azhary, 1992: 13).

Kendatipun wakaf memiliki potensi besar jika dikelola dengan baik namun realitasnya menunjukkan bahwa sampai saat ini asset wakaf atau tanah wakaf kerap terabaikan. Pengelolaan wakaf sangat memprihatinkan akibatnya banyak tanah wakaf terlantar dan tidak produktif.

Di Indonesia, pada aspek pertumbuhan ekonomi yang masih memprihatinkan, diperlukan perananan wakaf sebagai instrumen ekonomi Islam, (zakat, infaq, sedekah) agar dapat lebih dirasakan manfaatnya sebagai peningkatan taraf kehidupan umat di bidang ekonomi, sehingga perlu pengelolaan harta wakaf yang masih bersifat tradisional untuk dapat dikelola secara professional sehingga tujuan pemanfaatan wakaf dapat terwujud.

Oleh karena itu, di Indonesia dalam hal pengelolaan dan pengembangan wakaf dibutuhkan peran bersama pemerintah, ulama dan masyarakat. Hal lain adalah harta yang diwakafkan, dalam aspek peruntukannya dapat dikelolah secara professional oleh Nazhir dan wakaf tersebut diserahkan pada badan-badan khusus yang memiliki kompetensi memadai yang dapat dikelolah secara profesional dan amanah.

Permasalahan-permasalahan yang terdapat di masyarakat pada aspek pemanfaatan wakaf merupakan hambatan yang mengganjal. Adapun permasalahan yang ada dapat dikelompokkan menjadi 2 hal, Pertama pada aspek adminstratif (tanah wakaf belum semuanya dibuatkan akta ikar wakaf oleh pejabat yang berwenang yang disebabkan oleh tanah wakaf yang tidak memiliki dokumen dan pemenuhan kewajiban finansial sebagai persyaratan dokumen, sehingga akan berimplikasi pada ketidakpastian status tanah wakaf. Kedua aspek non adminstrasi, yakni belum terbinanya dengan baik para fungsionaris nazhir tentang posisi, tugas dan tanggung jawabnya secara profesional. Permasalahan tersebut akan berdampak pada tidak tercapainya produktifikat wakaf.

Hal ini tentunya sangat erat kaitannya dengan pedoman kerja Badan Pertanahan Nasional yang pernah berlaku yang disebut Catur Tertib Pertanahan, yaitu (1) Tertib hukum pertanahan (2) Tertib administrasi pertanahan (3) Tertib Peruntukan dan pemanfaatan tanah, dan (4) tertib pelestarian lingkungan hidup; nampaknya dalam kaitannya dengan masalah wakaf masih jauh dari memuaskan. 


\section{SIMPULAN}

Berdasarkan uraian di atas bahwa Eksistensi tanah wakaf adalah mengekalkan manfaat benda wakaf sesuai dengan tujuan wakaf, yakni mewujudkan potensi dan manfaat ekonomis harta benda wakaf untuk kepentingan ibadah dan untuk memajukan kesejahteraan umum. Tata kelola Tanah wakaf dalam Pemanfaatannya diperlukan komitmen bersama pemerintah, ulama, dan masyarakat. Selain itu juga harus direstrukturisasi atau penataan kembali mengenai hal yang berkenaan dengan wakaf, termasuk harta yang diwakafkan, peruntukan wakaf dan Nazhir serta pengelolaan wakaf secara professional dan amanah sehingga bisa produktif.

\section{DAFTAR PUSTAKA}

Ana

Ramadhona, Pelaksanaan Konsolidasi Tanah Perkotaan Untuk Pembangunan Jalan By Pass Di Kota Bukittinggi, Jurnal Cendekia Hukum, Vol. 3, No. 1, 2017.

Busthanul Arifin, Transformasi Hukum Islam ke Hukum Nasional Yayasan Al-Hikmah, Jakarta, 2001.

Departemen Agama RI, Al-Qur'an dan Terjemahannya, Bandung:

Diponegoro, 2006

Departemen Agama RI, Perkembangan Pengelolaan Wakaf di Indonesia tahun, Jakarta, Proyek Pengelolaan Zakat danWakaf. Direktorat Jenderal Bimbingan Masyarakat Islam dan Penyelenggaraan Haki, 2003.

Departemen Agama RI, Paradigma Baru Wakaf di Indonesia, Jakarta,
Direktorat Pemberdayaan Wakaf

Direktorat Jendral Bimbingan Masyarakat Islam, 2006.

Departemen Agama RI, Peraturan Pemerintah Perwakafan, Jakarta, DirjenBIMAS, 2001.

Departemen Agama RI, Undang-undang Perwakafan, Jakarta, Direktorat Pemberdayaan Wakaf Direktorat Jendral Bimbingan Masyarakat Islam, 2006.

Departemen Agama RI, Proses Lahirnya Undang-undang Nomor 41 Tahun 2004, tentang Wakaf, Jakarta, Direktorat Pembedayaan wakaf Direktorat Jenderal Bimbingan Masyarakat Islam Departeman Agama, 2006.

Departemen Agama RI, Peraturan Perundangan Perwakafan.

Elfira Permatasari, Habib Adjie \& Hardianto Djanggih, Perlindungan Hukum Kepemilikan Tanah Absentee yang Diperoleh Akibat Pewarisan, Jurnal Varia Justisia, Vol. 14, No.1, 2018.

Nasrun Hipan, Nirwan Moh Nur, \& Hardianto Djanggih. "Problematika Penyelesaian Sengketa Tanah Di Lokasi Tanjung Sari Kabupaten Banggai." Law Reform Vol. 14, No. 2, 2018.

M. Thaher Azhary, Wakaf dan Sumber Daya Ekonomi, Suatu Pendekatan Teoritis, Mimbar Hukum No. 7 Tahun III, Jakarta, Al-Hikmah dan Direktorat Pembinaan Badan Peradilan Agama Islam, 1992.

Martono, Metode Penelitian Kuantitatif. Jakarta, Rajawali Pres. 2010. 
Salmawati: Eksistensi Tanah Wakaf Dalam Pemanfaatannya Untuk Kemajuan...

Nova Yarsina, Perlindungan Hukum Terhadap Tanah Ulayat Yang Telah Bersertifikat Di Kota Bukittinggi, Jurnal Cendekia Hukum, Vol. 3, No. 2, 018.

Rachmat Djatniko, Wakaf dan Masyarakat serta Aplikasinya Aspek-aspek Fundamental, Jakarta, Mimbar Hukum, al-Hikmah dan Direktorat Pembinaan Badan Peradilan Agama Islam, 1992.

Roihan A. Rasyid, Hukum Acara Peradilan Agama (Edisi Baru), PT Raja Grafindo Persada, Jakarta, 1998, Cet. VIII.
Sayyid Sabiq, Fiqih Sunnah 14, Bandung; PT. Al-Ma'arif, 1988.

Zainal Arifin Munir, Revitalisasi Manajemen Wakaf Sebagai Penggerak Ekonomi Masyarakat, Jurnal Hukum Dan Syariah De Jure, Vol. 5, No. 2, 2013.

http://siwak.kemenag.go.id/tabel_jumlah_ tanah_wakaf.php 